\title{
EVALUATION OF IN VIVO IMMUNOMODULATORY ACTIVITY OF AQUEOUS AND ETHANOLIC EXTRACT OF EULOPHIA NUDA L.
}

\author{
VANITA KANASE*, DIPTESH T PATIL \\ Department of Pharmacology, Oriental College of Pharmacy, Sanpada, Navi Mumbai - 400 705, Maharashtra, India. \\ Email id: vanita.kanase@gmail.com
}

Received: 02 May 2018, Revised and Accepted: 09 August 2018

\section{ABSTRACT}

Objective: The aim of this study was to evaluate the in vivo immunomodulatory activity of an aqueous and ethanolic extract of dried tubers of Eulophia nuda (ENA and ENE)

Methods: Effect of both the extracts was evaluated on delayed-type hypersensitivity (DTH) response, serum antibody response, and cyclophosphamideinduced myelosuppression in Swiss albino mice.

Results: The extracts showed stimulation of DTH reaction in mice in response to T-cell dependent antigen by both ENE () and ENA (); significant increase in serum antibody titer at of ENA (768.01) and ENE (768.33) extract at $200 \mathrm{mg} / \mathrm{kg}$, compared to control group (213.33); Combined treatment of ENA+Cytochromes P450 [CYP]-25 mg/kg and ENE+CYP-25mg/kg (50,100, and $200 \mathrm{mg} / \mathrm{kg})$ doses of ENA and ENE each with $25 \mathrm{mg} / \mathrm{kg}$ resulted in restoration of bone marrow activity as compared with CYP treatment alone.

Conclusion: Both specific and non-specific immunostimulating properties of the ENE and ENA tubers in in vivo experimental methods suggest its therapeutic usefulness in immunocompromised conditions.

Keywords: Eulophia nuda L., Peritoneal macrophages, Nitric oxide, Carbon clearance, Ovalbumin antibody titer.

(C) 2018 The Authors. Published by Innovare Academic Sciences Pvt Ltd. This is an open access article under the CC BY license (http://creativecommons. org/licenses/by/4. 0/) DOI: http://dx.doi.org/10.22159/ajpcr.2018.v11i12.27051

\section{INTRODUCTION}

The immune system is known to be involved in the etiology as well as pathophysiological mechanisms of many diseases [1]. Ayurveda gives emphasis on promotion of health - A concept of strengthening host defenses against different diseases [2]. Rasayana plants are particularly recommended for the treatment of immune disorder [3], Ayurveda (with particular reference to plants) may play an important role in modern health care, particularly where satisfactory treatment is not available. There is need to evaluate the potential of Ayurvedic remedies to the advantage of counteract side effect of modern therapy and compare the cost-effectiveness of certain therapies vis-a-vis modern therapeutic schedules [4]. Development of agents capable of moving "patients" immune system from a state of immune deficiency to one or more normal function would likely to have a significant impact on disease and the patient it affects. Such agent would not be a cure but would control the manifestation and course of disease [5-7].

Eulophia nuda L., Orchidaceae family, is a perennial, terrestrial herb with underground tubers found in central and Southeast Asian regions. In India, this plant is found in the tropical Himalayas, from Nepal to Assam, and in Deccan from Konkan southwards. The tubers are reported to be used against tumors, scrofulous glands of the neck, bronchitis, blood disease, and as a vermifuge [8-12]. In Thailand, this orchid is used in traditional medicines for the treatment of skin rash. Raw tubers are eaten for curing rheumatoid arthritis [13]. Recently, it is reported to be demulcent and anthelmintic in action [14]. Underground part (tubers) also called as Salep is used as an aphrodisiac drug [15]. They are also used to treat acidity, piles, and stomach complaints [16,17].

\section{METHODS}

Plant material and preparation of extract

Fresh tubers of E. nuda L. were collected from Bhimashankar region of the Western Ghats in Pune district, India, in May 2012 and authenticated from Blatter Herbarium, St. Xavier's College, Mumbai - 400 001. The voucher specimen number is 20831; specimen sample was deposited in the herbarium of the institute for future reference. The tubers were thoroughly washed cut into small pieces and dried at controlled temperature of $45^{\circ} \mathrm{C}$ and powdered. The powder was then extracted with boiling ethanol under soxhlation to give an ethanolic extract of E. nuda (ENE) and similarly with boiling water under soxhlation to give an aqueous extract of $E$. nuda (ENA). The extracts were evaporated to dryness. The yield of ethanolic and water extract was obtained $7.5 \%$ and $9 \%$ for ENE and ENA extract, respectively.

Preliminary phytochemical screening

The ENE and ENA were subjected to preliminary phytochemical screening [18] for the detection of various plant constituents.

\section{Experimental animals}

Swiss albino mice were obtained from National Toxicology Centre, Pune. The animals were acclimatized for 10 days before being used for the experiments. They were housed in a room with controlled temperature $\left(23 \pm 20^{\circ} \mathrm{C}\right)$ and a 12 -h light/12-h dark cycle. The animals were fed with standard pellet diet and water ad libitum.

The experimental protocols were approved by the Institutional Animal Ethics Committee of the National Toxicology Centre, Pune, and conducted according to the guidelines of the Committee for the Purpose of Control and Supervision on Experiments on Animals, India (Research project No. 159).

\section{Acute oral toxicity studies}

Acute oral toxicity studies were carried out for ENA and ENE as per the organization for economic cooperation and development guideline number $423[19,20]$.

\section{Chemicals}

Ovalbumin, Freund's complete adjuvant (FCA), and bovine serum albumin (BSA) were procured from Bangalore Genei, India. Streptomycin, 
penicillin, Roswell Park Memorial Institute (RPMI) 1640 medium, and HEPES buffer were procured from HiMedia Pvt., Ltd., India. Fetal bovine serum (FBS) and phytohemagglutinin-M (PHA) were procured from Sigma-Aldrich (St. Louis, MO, USA). All other chemicals used were of analytical grade.

\section{In vivo phagocytic activity by carbon clearance assay}

Phagocytic activity of both extracts was determined as per the method described by Yan et al. 2007 [21]. Mice were divided into nine groups, of six each. The vehicle control group received $(0.5 \%$ sodium carboxymethyl cellulose $[\mathrm{NaCMC}])$. Positive control group received immunosin $50 \mathrm{mg} / \mathrm{kg}$. Negative control group received cyclophosphamide $10 \mathrm{mg} / \mathrm{kg}$. Mice in the treatment groups were administered orally ENA and ENE extracts each $(50,100$, and $200 \mathrm{mg} / \mathrm{kg}$ ) suspended in vehicle daily for 20 days. Colloidal carbon solution, Rotring ink ${ }^{\circledR}$ (Hamburg, Germany) was diluted with normal saline (1:8), and injected ( $0.01 \mathrm{ml} / \mathrm{g}$ body weight) was through tail vein to each mouse $24 \mathrm{~h}$ after the last dose. Blood samples were drawn from the retro-orbital plexus under ether anesthesia at 2 and 15 min after injection. Blood ( $25 \mu \mathrm{l})$ was mixed with $0.1 \%$ sodium carbonate $(2 \mathrm{ml})$ for the lysis of erythrocytes OD was recorded at $660 \mathrm{~nm}$. The phagocytic index $(\mathrm{K})$ was calculated using the following equation:

$$
\mathrm{K}=\frac{\ln \mathrm{OD} 1-\ln \mathrm{OD} 2}{\mathrm{~T} 2-\mathrm{T} 1}
$$

Where, OD1 and OD2 are the optical densities at times T1 and T2, respectively [22].

\section{Immunization and treatment}

Mice were divided into nine groups of six each. The vehicle control group received $0.5 \% \mathrm{NaCMC}$ and positive control group received immunosin $50 \mathrm{mg} / \mathrm{kg}$. Negative control group received cyclophosphamide $10 \mathrm{mg} /$ $\mathrm{kg}$; while mice in the treatment groups were administered with the ENA and ENE extract each (50,100, and $200 \mathrm{mg} / \mathrm{kg}$, p.o.) in vehicle daily for 20 days. On the $14^{\text {th }}$ day, the animals were immunized subcutaneously with ovalbumin $(3 \mathrm{mg})$ dissolved in normal saline emulsified with an equal volume of FCA.

\section{Delayed type hypersensitivity (DTH) response}

To assess the DTH response, mice were challenged subcutaneously with $25 \mu \mathrm{g}$ ovalbumin in $25 \mu \mathrm{l}$ normal saline in the left hind footpad 7 days after the immunization. The right hind footpad was injected with $25 \mu \mathrm{l}$ vehicle and served as control. The increase in footpad thickness was measured $24 \mathrm{~h}$ after the challenge with the help of a digimatic caliper (Mitutoyo Corporation, Japan) [23]

\section{Detection of serum antibody response}

Blood was collected from mice through retro-orbital plexus after 7 days of immunization and serum was separated under centrifugation. Serum antibody titers for quantification of serum IgG to ovalbumin were estimated by ELISA as described earlier [23]. Flat bottom polystyrene plates were coated with $12.5 \mu \mathrm{g}$ of ovalbumin dissolved in $100 \mu \mathrm{l}$ of sodium carbonate buffer $(\mathrm{pH} 9.6)$ at $4^{\circ} \mathrm{C}$ for $12 \mathrm{~h}$. The coated plates were washed 3 times with phosphate buffer saline (0.15 M, pH 7.2) containing $0.05 \%$ TWEEN-20 (PBS-Tw). The wells were incubated with $100 \mu \mathrm{l}$ of $1 \% \mathrm{BSA}$ in sodium carbonate buffer at $37^{\circ} \mathrm{C}$ for $1 \mathrm{~h}$. Serial dilutions of mouse serum samples in PBS-Tw were prepared, and $100 \mu \mathrm{l}$ was incubated with coated wells for $1 \mathrm{~h}$ at $37^{\circ} \mathrm{C}$. After washing, diluted (1:2000) anti-mouse IgG conjugated with peroxidase $(100 \mu \mathrm{l})$ was added, and the plates were incubated at $37^{\circ} \mathrm{C}$ for $1 \mathrm{~h}$. The enzyme activity was determined by addition of TMB $/ \mathrm{H}_{2} \mathrm{O}_{2}$. The enzyme reaction was stopped by addition of $50 \mu \mathrm{l}, 8 \mathrm{~N}$ sulfuric acid, and the absorbance was measured at $450 \mathrm{~nm}$. Endpoint antibody titers were expressed as the reciprocal of the highest dilution of the test serum samples showing 3 times more OD as compared with control samples.

\section{Cyclophosphamide-induced myelosuppression}

This experiment was studied according to the procedure described earlier with some modifications [24]. Mice were divided into nine groups of six each. The vehicle control group received $(0.5 \% \mathrm{NaCMC})$; positive control group received immunosin $50 \mathrm{mg} / \mathrm{kg}$. Negative control group received cyclophosphamide $25 \mathrm{mg} / \mathrm{kg}$, while mice in the treatment groups were administered with the ENA and ENE extract each $\left(50,100\right.$, and $200 \mathrm{mg} / \mathrm{kg}$, p.o.) in vehicle daily for 19 days. On $17^{\text {th }}$, $18^{\text {th }}$, and $19^{\text {th }}$ day of study, all the animals except in the vehicle control group were injected with cyclophosphamide $(25 \mathrm{mg} / \mathrm{kg}$, i.p.,) $1 \mathrm{~h}$ after administration of the extract or vehicle. Blood samples were collected on day 20 , and total blood cell count was determined using hematology analyzer (Arcus, Diatron, Wien Austria).

\section{Statistical analysis}

Results are expressed as mean \pm SEM. Data were analyzed by one-way ANOVA followed by Dunnett's multiple comparisons test with $\mathrm{p}<0.05$ as the criteria for significance.

\section{RESULTS}

\section{Extraction}

The yield of ethanolic and water extract was obtained 9.5\% and 11\% for ENE and ENA, respectively. The extract showed the presence of phytosterols, saponins, proteins, alkaloids, glycosides, and flavonoids.

\section{Pharmacological activity \\ In vivo phagocytic activity by carbon clearance assay}

In vivo phagocytic activity of ENA and ENE extracts was determined by the carbon clearance assay in mice. The results are presented in Table 1 . The phagocytic index $(\mathrm{K})$ for ENA extract was significantly higher $(\mathrm{p}<0.05)$ at $50 \mathrm{mg} / \mathrm{kg}(15.86 \%), 100 \mathrm{mg} / \mathrm{kg}$ (32.06\%), and $200 \mathrm{mg} / \mathrm{kg}$ (35.47\%), and for ENE extract was significantly higher $(\mathrm{p}<0.05)$ at $50 \mathrm{mg} / \mathrm{kg}(14.8 \%)$, $100 \mathrm{mg} / \mathrm{kg}(31.9 \%)$, and $200 \mathrm{mg} / \mathrm{kg}$ (41.12\%) dose levels as compared to control group. Positive control immunosin (50 mg/kg) showed $71.2 \%$ higher K compared to the control group (Fig. 4).

\section{DTH response in ovalbumin immunized mice}

To examine the effect of ENA and ENE extracts on the cellular immune system, its activity was investigated as DTH reaction to ovalbumin immunized mice. The DTH response, i.e. difference in footpad thickness of mice is shown in Table 1. Both aqueous and ethanolic extracts produced a significant increase in the DTH response to ovalbumin at all the tested dose levels. Increase in DTH reaction in mice in response to $\mathrm{T}$ cell-dependent antigen revealed the stimulatory effect of aqueous and ethanolic extract on T cells (Fig. 2). Immunosin $50 \mathrm{mg} / \mathrm{kg}$ and ENA and ENE 100 and $200 \mathrm{mg} / \mathrm{kg}(\mathrm{p}<0.05)$ compared to control group.

\section{Detection of serum antibody response to ovalbumin}

Humoral response to ovalbumin was studied by ELISA antibody titer assay. Mice treated with different doses of the ENA and ENE extract showed an increase in the antibody titer in a dose-dependent manner. There was significant increase in serum antibody titer at $200 \mathrm{mg} / \mathrm{kg}$ (768.01) $(\mathrm{p}<0.05)$ of ENA extract compared to control group (213.33) and significant increase in serum antibody titer at $200 \mathrm{mg} / \mathrm{kg}$ (768.33) $(p<0.05)$ of ENE extract compared to the control group (213.33) (Table 1). Positive control immunosin $(50 \mathrm{mg} / \mathrm{kg}$ ) showed (1195.00) $(\mathrm{p}<0.05)$ compared to control group (Fig. 3 ).

\section{Cyclophosphamide-induced myelosuppression}

There was a significant reduction $(\mathrm{p}<0.05)$ in total white blood cell (WBC) count of cyclophosphamide $(25 \mathrm{mg} / \mathrm{kg})$ treated mice $(8.792$ $\times 10^{3}$ cells $\left./ \mathrm{cmm}\right)$ as compared to vehicle control group (13.38 $\times$ $10^{3}$ cells $/ \mathrm{cmm}$ ). Cyclophosphamide dose of $25 \mathrm{mg} / \mathrm{kg}$ caused a significant reduction in the WBC, red blood cell (RBC), hemoglobin, and platelet count. Combined treatment of ENA+cytochromes P450 [CYP] $-25 \mathrm{mg} / \mathrm{kg}$ and ENE+CYP-25 mg/kg $(50,100$, and $200 \mathrm{mg} / \mathrm{kg})$ doses of ENA and ENE each with $25 \mathrm{mg} / \mathrm{kg}$ resulted in the restoration of bone marrow activity as compared with CYP treatment alone.

\section{DISCUSSION}

Immunomodulation through stimulation or suppression may help in maintaining a disease-free state. Agents that activate host defense 
Table 1: Effects of ENE and ENA on phagocytic index, DTH, and antibody titer

\begin{tabular}{|c|c|c|c|c|}
\hline S. No. & Treatment group (dose mg/kg) & Phagocytic index (K) & DTH mm ( $\left.\times 10^{-2}\right)$ & Antibody titer \\
\hline 1 & Vehicle control & $0.0561 \pm 0.0014$ & $23.67 \pm 0.49$ & $213.3 \pm 26.9$ \\
\hline 2 & CYP 10 & $0.0264 \pm 0.0010$ & $18.67 \pm 0.88$ & $149.3 \pm 21.3$ \\
\hline 3 & Immunosin-50 & $0.0960 \pm 0.0010$ & $38.63 \pm 0.89$ & $1195.0 \pm 170.6$ \\
\hline 4 & ENA 50 & $0.0650 \pm 0.0025$ & $26.33 \pm 0.76$ & $298.7 \pm 42.6$ \\
\hline 5 & ENA 100 & $0.0741 \pm 0.0013$ & $29.33 \pm 0.49$ & $341.3 \pm 53.9$ \\
\hline 6 & ENA 200 & $0.0760 \pm 0.0021$ & $31.67 \pm 0.49$ & $768.6 \pm 114.5$ \\
\hline 7 & ENE 50 & $0.0644 \pm 0.0011$ & $26.17 \pm 0.48$ & $341.3 \pm 53.9$ \\
\hline 9 & ENE 200 & $0.0831 \pm 0.0013$ & $29.17 \pm 0.48$ & $768.0 \pm 114.5$ \\
\hline
\end{tabular}

DTH: Delayed-type hypersensitivity. ENE: Ethanolic extracts of E. nuda L., ENA: Aqueous extracts of E. nuda L., E. nuda: Eulophia nuda, CYP: Cytochromes P450

Table 2: Effects of ENA and ENA on total WBC, RBC count, hemoglobin concentration, and platelet count

\begin{tabular}{|c|c|c|c|c|c|}
\hline S. No. & Treatment group (dose $\mathrm{mg} / \mathrm{kg}$ ) & $\begin{array}{l}\text { Total WBC count in } \\
\text { thousand }(\mathrm{cmm})\end{array}$ & $\begin{array}{l}\text { RBC count in }(\%) \\
\text { million }(\mathrm{cmm})\end{array}$ & $\begin{array}{l}\text { Hemoglobin } \\
\text { concentration in } \mathrm{g}\end{array}$ & $\begin{array}{l}\text { Platelet count in } \\
\text { thousands }(\mathrm{cmm})\end{array}$ \\
\hline 1 & Vehicle Control & $13.38 \pm 0.315$ & $7.19 \pm 0.153$ & $12.06 \pm 0.192$ & $498.29 \pm 3.42$ \\
\hline 2 & CYP (25) & $8.792 \pm 0.206$ & $5.88 \pm 0.105$ & $7.81 \pm 0.302$ & $432.43 \pm 3.71$ \\
\hline 3 & (Immunosin (50)+CYP (25) & $12.030 \pm 0.163$ & $8.09 \pm 0.181$ & $12.12 \pm 0.193$ & $540.24 \pm 1.08$ \\
\hline 4 & ENA (50)+CYP (25) & $9.260 \pm 0.140$ & $5.98 \pm 0.190$ & $10.65 \pm 0.142$ & $451.26 \pm 4.91$ \\
\hline 5 & ENA (100)+CYP (25) & $10.540 \pm 0.280$ & $6.34 \pm 0.226$ & $11.15 \pm 0.169$ & $482.15 \pm 4.27$ \\
\hline 6 & ENA (200)+CYP (25) & $11.470 \pm 0.203$ & $7.13 \pm 0.168$ & $11.35 \pm 0.207$ & $495.23 \pm 1.59$ \\
\hline 8 & ENE (100)+CYP (25) & $10.643 \pm 0.240$ & $6.79 \pm 0.187$ & $11.04 \pm 0.129$ & $456.46 \pm 0.67$ \\
\hline 9 & ENE (200)+CYP (25) & $10.900 \pm 0.090$ & $6.73 \pm 0.155$ & $11.35 \pm 0.188$ & $475.84 \pm 1.19$ \\
\hline
\end{tabular}

ENE: Ethanolic extracts of E. nuda L., ENA: Aqueous extracts of E. nuda L., E. nuda: Eulophia nuda, CYP: Cytochromes P450, WBC: White blood cell, RBC: Red blood cell

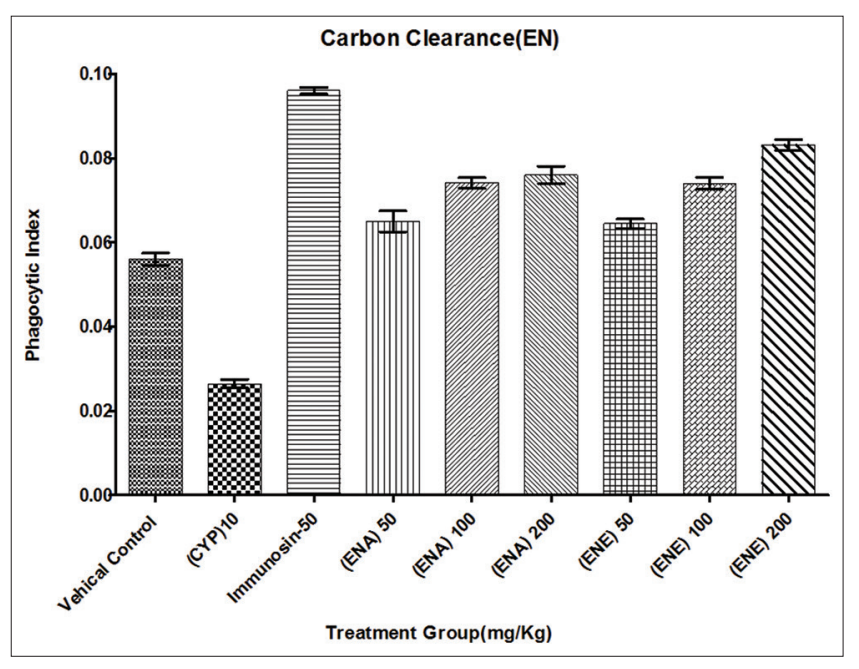

Fig. 1: Effects of ethanolic and aqueous extracts of Eulophia nuda L. on carbon clearance

mechanisms in the presence of an impaired immune responsiveness can provide supportive therapy to conventional chemotherapy [25]. There is a growing interest in identifying herbal immune modulators ever since their possible use in modern medicine has been suggested [26]. The main objective of the study was to investigate the immune modulatory effects of ENA and ENE.

Macrophages have been known to play an important role in the host protection against a wide range of tumors and microorganisms. Macrophages also present antigen to lymphocytes during the development of specific immunity and serve as supportive accessory cells to lymphocytes. When activated, macrophages increase the phagocytic activity and release various materials such as cytokines and reactive intermediates and then carry out non-specific immune responses. There has been great interest in reactive nitrogen intermediates, nitric oxide (NO), because of its antibacterial and antitumor effect [27]. NO mediates diverse functions, including vasodilatation, neurotransmission, and inflammation [28]. A very

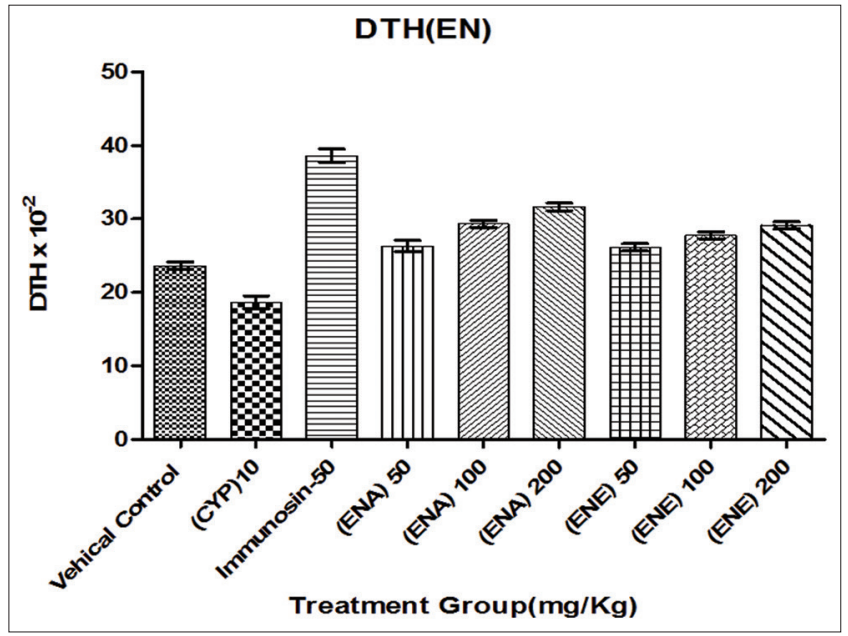

Fig. 2: Effects of ethanolic and aqueous extracts of Eulophia nuda L. on delayed-type hypersensitivity

high NO production indicates increased phagocytosis and bactericidal activity, which is supported by the data, presented in Fig. 1. Macrophages play an important role in defense mechanism against host infection and in killing tumor cells. Higher reduction of nitroblue tetrazolium (NBT) dye by ENA and ENE extract represents a higher activity of oxidase enzyme, reflecting stimulation of phagocytes in proportion to intracellular killing. For lysosomal enzyme activity, the transformation of para-nitrophenylphosphate to colored compound by the acid phosphatase of the stimulated macrophages correlates to the extent of degranulation in phagocytosis $[6,29]$. Phagocytosis of particles by macrophages is usually accompanied by a burst of oxidative metabolism allowing the generation of reactive oxygen species which can be detected through an assay based on the reduction of NBT [30]. The effect of various concentrations of ENA and ENE extracts on the reduction of NBT dye and lysosomal enzyme activity response of macrophages was studied for phagocytic assay. ENA and ENE extracts appeared to produce phagocytic stimulation with doseresponse relationship in lysosomal enzyme activity evaluation. 


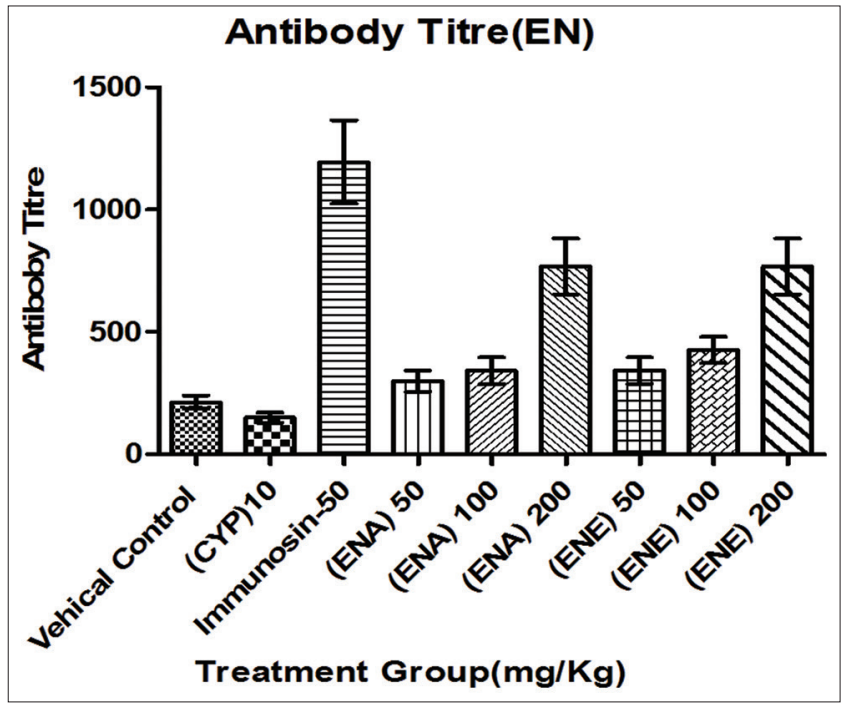

Fig. 3: Effects of ethanolic and aqueous extracts of Eulophia nuda L. on serum antibody response to ovalbumin
Myeloperoxidase, a heme protein secreted by neutrophils and macrophages, which uses the oxidizing potential of $\mathrm{H}_{2} \mathrm{O}_{2}$ to convert chloride ion into hypochlorous acid ( $\mathrm{HOCl}$ ). A potent bactericidal agent, $\mathrm{HOCl}$ is a critical component of host defenses against invading bacteria, fungi, and viruses [7,31]. The increase in the stimulation index of myeloperoxidase by the exposure of ENA and ENE extracts indicates the enhanced defense capability of these cells to pathogenic organisms. The release of immune mediators from murine peritoneal macrophages was significantly stimulated by the exposure of the extract. Murine isolated peritoneal macrophages incubated with the ENA and ENE extracts at different concentrations ranging between 832 and $6.5 \mu \mathrm{g} / \mathrm{ml}$ for $24 \mathrm{~h}$, showed significant activation of macrophages by modulating the secretion of various mediators including NO, lysosomal enzyme, and myeloperoxidase activity. This suggests that ENA and ENE extracts can effectively strengthen innate immunity against foreign particles [32].

The process of phagocytosis involves certain body cells, known as phagocytes, which ingest and removes microorganisms, malignant cells, inorganic particles, and tissue debris [33]. Phagocytosis and killing of invading microorganisms by macrophages constitute body's primary line of defense. Macrophages are an integral part of the immune system, acting as phagocytic, microbicidal, and tumoricidal effector cells [34].

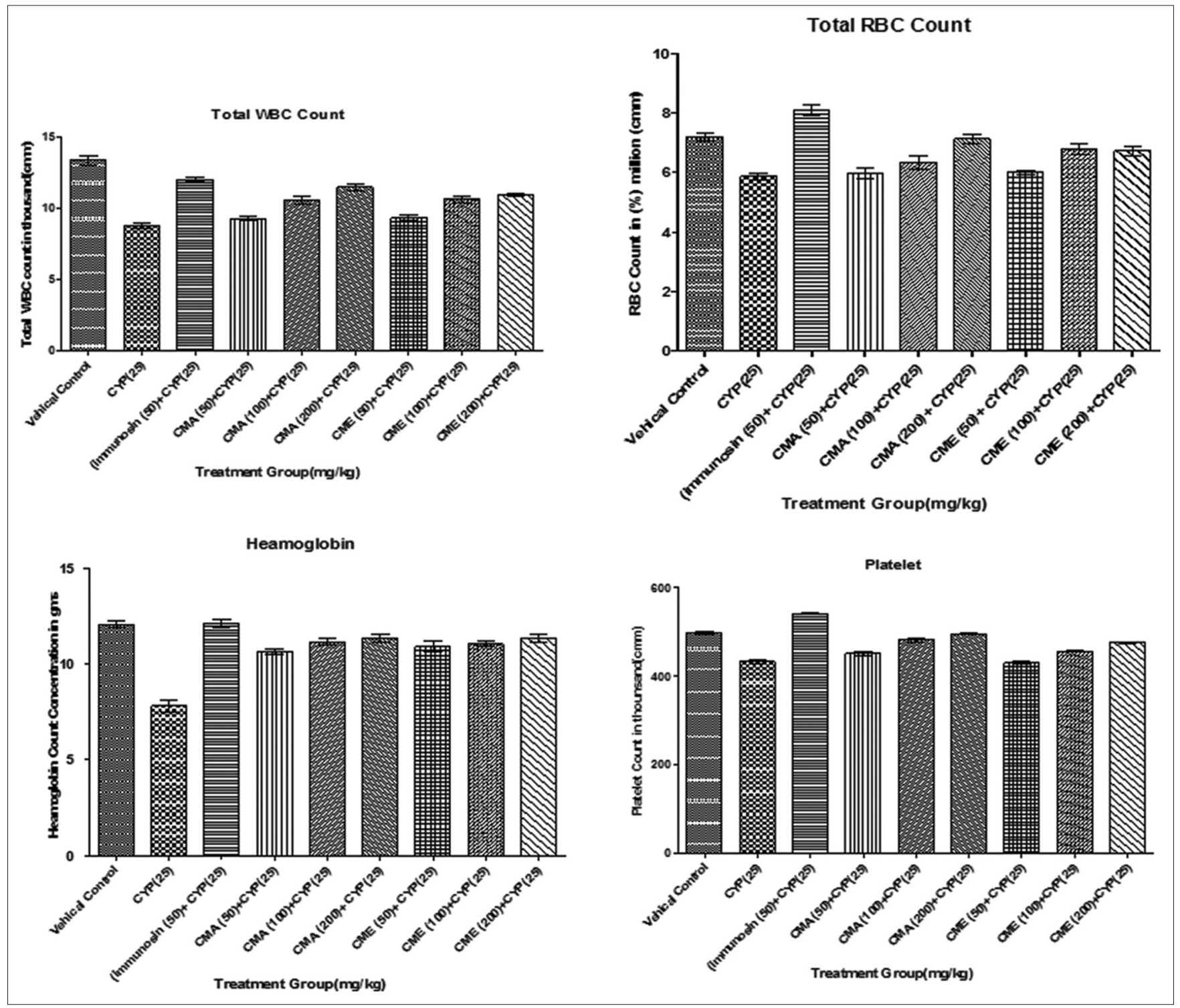

Fig. 4: Effects of ethanolic and aqueous extracts of Eulophia nuda L. on total white blood cell, RBC count, hemoglobin concentration, and platelet count 
Through interaction with lymphocytes, macrophages play an important role in the initiation and regulation of immune response [27]. In view of the pivotal role played by the macrophages, ENA and ENE extracts were also evaluated for it's in vivo effect on macrophage phagocytic activity. The increase in carbon clearance, i.e. phagocytic index by NNA and ENE extracts reflects the enhancement of phagocytic function of mononuclear macrophage and thus non-specific immunity. This indicates that ENA and ENE extracts were able to activate murine peritoneal macrophages, and hence phagocytic assays in vitro and in vivo.

The effect of the ENA and ENE extracts on cell-mediated immunity (CMI) was evaluated through DTH reaction to ovalbumin, a T celldependent antigen. CMI responses are critical to defend against infectious organisms, infection of foreign grafts, tumor immunity, and DTH reaction (Miller, 1991). Therefore, increase in DTH reaction in mice in response to $\mathrm{T}$ cell-dependent antigen revealed the stimulatory effect of ENE and ENA (Table 2). The T and B cell cognate interaction provides an optimal signal for B cell differentiation and antibody production toward $\mathrm{T}$ dependent antigen (ovalbumin) [33]. The augmentation of the humoral immune response to ovalbumin by ENA and ENE extracts, as evidenced by an increase in the antibody titer in mice indicated the enhanced responsiveness of $\mathrm{T}$ and $\mathrm{B}$ lymphocyte subsets, involved in the antibody synthesis [35].

A high degree of cell proliferation renders the bone marrow a sensitive target, particularly to cytotoxic drugs. In fact, bone marrow is the organ most affected during any immunosuppressive therapy, especially with cyclophosphamide. Loss of stem cells and the inability of the bone marrow to regenerate new blood cells results in thrombocytopenia and leukopenia [36,37]. Since E. nuda augmented the circulating antibody titer, it was thought worthwhile to evaluate its effect on peripheral blood count and cyclophosphamide-induced immunosuppression. The administration of E. nuda significantly ameliorated the total WBC count, RBC count, hemoglobin, and platelet count and also restored the myelosuppressive effects induced by cyclophosphamide (Table 2). The present investigation suggests that $E$. nuda may stimulate both cellular and humoral immune responses. Further studies to elucidate the exact immunostimulatory mechanism of $E$. nuda need to be explored.

\section{CONCLUSION}

The studies have demonstrated specific and non-specific immunostimulating properties of the ENE and ENA tubers in in vivo experimental methods. This suggests its therapeutic usefulness in immunocompromised conditions.

\section{ACKNOWLEDGMENT}

The authors are thankful to Dr. Kishori G. Apte, Director, Technical of APT Testing and Research Pvt., Ltd., Pune, for their support and guidance.

\section{AUTHORS' CONTRIBUTION}

We declare that this work was done by the authors named in this article and all liabilities pertaining to claims relating to the content of this article will be borne by the authors. Dr. (Mrs.) Vanita G. Kanase collected the data, prepared the protocol, conduct the research and assesses the manuscript. Mr. Diptesh T. Patil prepared Manuscript, provided the statistical assessment of data and suggested the necessary changes, and helps in designing manuscript.

\section{CONFLICTS OF INTEREST}

The authors declare that there are no conflicts of interests regarding the publication of this paper.

\section{REFERENCES}

1. Sharma P. Charak Samhita. $1^{\text {st }}$ ed. Varanasi: Chaukhambha Orientalia; 1983. p. 54.

2. Thatte U, Dahanukar S. Ayurveda and contemporary scientific thought.
Trends Pharmacol Sci 1986;7:247-51.

3. Dhanukar SA, Thatte UM, Rege NM. In: Wagner $\mathrm{H}$, editor. Immunomodulatory Agents from Plants. Basel, Switzerland: Birkhauser Verlag; 1999. p. 289-323.

4. Dahanukar S, Thatte U. Current status of ayurveda in phytomedicine. Phytomedicine 1997;4:359-68.

5. Gottlieb A, Gottlieb M, Scholes V. Reconstitution of immune function in AIDS/ARC. Concept Immunopathol 1987;4:261-74.

6. Kanase V, Jain B, Yadav P. Evaluation of in-vitro immunomodulatory activity of aqueous and ethanolic extract of Capparis mooni. Int $\mathrm{J}$ Pharm Bio Sci 2013;4:344-52.

7. Kanase V, Jain B, Yadav P. Evaluation of in-vitro immunomodulatory activity of hydroalcoholic extract of Ceropegia Bulbosa Roxb. Int J Res Sci Innov 2016;3:36-40.

8. Kirtikar K, Basu B. Indian Medicinal Plants. Vol. IV. Varanasi: Lalit Mohan Basu; 1918. p. 2405.

9. The Wealth of India: A Dictionary of Indian Raw Materials and Industrial Products. Vol. III). New Delhi: Publications and information Directorate; 1966. p. 221-2.

10. Chopra R, Nayar S, Chopra I. Glossary of Indian Medicinal Plants. New Delhi: Council of Scientific and Industrial Research; 1956. p. 221.

11. Cooke T. The Flora of the Presidency of Bombay. Calcutta: Botanical Survey of India; 1967. p.197-8.

12. Nadkarni K. Indian Materia Medica. Mumbai: Popular Prakashan Private Ltd; 1976. p. 519.

13. Mali P, Bhadane V. Some rare plants of ethnomedicinal properties from Jalgaon district of Maharashtra. Int J Green Pharm 2008;2:76-8.

14. Singh A, Duggal S. Medicinal orchids: An overview. Ethnobotanical leaflets 2009;13:351-63.

15. Jagdale S, Shimpi S, Chachad D. Pharmacological studies of 'salep'. J Herbal Med Toxicol 2009;3:153-6.

16. Mahekar P, Yadav S. Medicinal Plants of South Western Maharashtra. In: Pullaiah T, editor. Biodiversity in India. New Delhi, India: Regency Publications; 2006. p. 561.

17. Shriram V, Kumar V, Kishor P, Suryawanshi S, Upadhyay A, Bhat M. Cytotoxic activity of 9,10-dihydro-2,5-dimethoxyphenanthrene-1,7diol from Eulophia nuda against human cancer cells. J Ethnopharmacol 2010;128:251-3.

18. Trease G, Evans W. Textbook of Pharmacognosy. 12 ${ }^{\text {th }}$ ed. London: Balliere, Tindall 1989. p. 343-83.

19. OECD Guidelines for the Testing of Chemicals: Guideline 423: Acute Oral Toxicity.; 2002. p. 1-14.

20. Litchfield J, Wilcoxon F. A simplified method of evaluating dose-effect experiments. J Pharm Exp Ther 1949;96:99-113.

21. Yan Y, Wanshun L, Baoqin H, Changhong W, Chenwei F, Bing L, et al. The antioxidative and immunostimulating properties of d-glucosamine. Int Immunopharmacol 2007;7:29-35.

22. Lee S, Suk K. Heme oxygenase-1 mediates cytoprotective effects of immunostimulation in microglia. Biochem Pharmacol 2007;74:723-9.

23. Popov S, Golovchenko V, Ovodova R, Smirnov V, Khramova D, Popova G, et al. Characterisation of the oral adjuvant effect of lemnan, a pectic polysaccharide of Lemna minor L. Vaccine 2006;24:5413-9.

24. Ghule B, Murugananthan G, Nakhat P, Yeole P. Immunostimulant effects of Capparis zeylanica Linn. leaves. J Ethnopharmacol 2006;108:311-5.

25. Wagner H. Immunostimulatory drugs of fungi and higher plants. In: Hikino NR, Farnsworth H, editors. Economic and Medicinal Plant Research. Vol. I. London: Academic Press; 1984. p. 113-53.

26. Tiwari U, Rastogi B, Singh P, Saraf D, Vyas S. Immunomodulatory effects of aqueous extract of Tridax procumbens in experimental animals. J Ethnopharmacol 2004;92:113-9.

27. Lowenstein CJ, Snyder SH. Nitric oxide, a novel biologic messenger. Cell 1992;70:705-7.

28. Saraphanchotiwitthaya A, Ingkaninan K, Sripalakit P. Effect of Bacopa monniera Linn. extract on murine immune response in vitro. Phytother Res 2008;22:1330-35.

29. Benencia F, Courrèges MC, Coulombié FC. Trichilia glabra: Effect on the phagocytic activity and respiratory burst response of peritoneal macrophages. Immunopharmacology 1999;41:45-53.

30. Brown, K., Brunt, E. and Heinecke, J. (2001). Immunohistochemical Detection of Myeloperoxidase and Its Oxidation Products in Kupffer Cells of Human Liver. The American Journal of Pathology, 159(6), pp.2081-2088.

31. Xie QW, Cho HJ, Calaycay J, Mumford RA, Swiderek KM, Lee TD, et al. Cloning and characterization of inducible nitric oxide synthase from mouse macrophages. Science 1992;256:225-8.

32. Miller LE. In: Ludke HR, Peacock JE, Tomar RH, editors. Manual of Laboratory Immunology. London: Lea and Febiger; 1991. p. 1-18. 
33. Stanilova S, Zhelev Z, Dobreva Z. Preliminary studies on the immunomodulatory effect of the $\mathrm{C} 3$ binding glycoprotein isolated from Cuscuta europea. Int J Immunopharmacol 2000;22:15-24.

34. Son E, Moon E, Rhee D, Pyo S. Stimulation of various functions in murine peritoneal macrophages by high mannuronic acid-containing alginate (HMA) exposure in vivo. Int Immunopharmacol 2000;1:147-54.

35. Shrestha P, Handral M. Evaluation of immunomodulatory activity of extract from rind of Nephelium lappaceum fruit. Int J Pharm Pharm Sci
2016;9:38

36. Lee S, Chary M, Salehi I, Bansal R. Immune-mediated Adalimumabinduced thrombocytopenia for the treatment of ulcerative colitis. Int $\mathrm{J}$ Pharm Pharm Sci 2018;7:456-8.

37. Agarwal R, Diwanay S, Patki P, Patwardhan B. Studies on immunomodulatory activity of Withania somnifera (Ashwagandha) extracts in experimental immune inflammation. J Ethnopharmacol 1999;67:27-35. 